\title{
Mapping the Terrain of Whiteness: Richard Wright's Savage Holiday
}

\section{Lâle Demirtürk}

University of Bilkent

Richard Wright's Savage Holiday, which focuses on how the white male protagonist Erskine Fowler deals with his guilt, has been ignored by critics until recently. Yoshinobu Hakutani maintains the reason why Savage Holiday has not received popularity among the critics is Wright's "exclusive treatment of white characters and his concern with nonracial matters" (15). J.F. Gounard and Beverley Roberts Gounard claim that "Savage Holiday is Richard Wright's only nonracial novel" (344), and they read the novel from a Freudian perspective in relationship to the Oedipal conflict between Fowler and his mother. John Vassilowitch also focuses on the "paradoxical connection between male sexual desire... and female degradation... [that] has its counterpart in Erskine's Oedipal fantasies about Mabel" (207). John M. Reilly analyzes the novel as a thriller and feels that it "omits racial conflict because its narrative scope is... restricted to the singular pattern of one man's Oedipal complex" (218). What all these critics have in common is a psychoanalytic exploration of Fowler's Oedipal conflict with his mother which draws him to the point of murdering Mabel. Michel Fabre is the only critic who gives an extensive study of the novel and of Fowler's profile as "a psychopathic murderer" (376).

The plot of the novel is simple. The 43-year-old Erskine Fowler is forced into early retirement from his job as insurance agent after 30 years of long service. As he picks up his Sunday paper, he is locked out of his apartment, fully naked, when the door slams shut. In a panic to avoid being seen by anyone, he decides to climb through his bathroom window just above the balcony on which his neighbor Mabel Blake's son Tony is playing. Seeing Fowler nude, Tony is shocked and falls from the balcony ten floors down to his death. Believing that Mabel may be aware he is indirectly responsible for Tony's death, Fowler becomes involved with Mabel, although she is just a whore in his eyes. Failing to deal with his own fear and guilt, he tries to make 
Mabel, a war widow, feel guilty for being a bad mother, for Tony got terribly scared whenever he saw his mother have sex with men, associating the sexual relationship with war in his mind. The naked body of Fowler apparently represented the "war" of which he has been deadly afraid. In order to "buy" Mabel's silence, Fowler makes a proposal to her, but Mabel is too clever for that. When she eventually discovers what Fowler had been up to, he kills her and turns himself in to the police. Before he confesses his murder to the police, he remembers his childhood memory of beating the doll's head with a brick because it is a "bad" woman-a replica of his mother, who was a prostitute. We realize that Fowler's revengeful act of crushing the doll and drawing the doll with his colored pencils to represent his mother's promiscuity is the reason why Mabel replaces his mother in his mind. All along he has failed to resolve the Oedipal conflict with his mother, who has deprived him of maternal affection, twisting his drive to love at an early age. He "resolves" the Oedipal conflict in killing in Mabel the mother that he has repudiated.

In an interview with Raymond Barthes on Savage Holiday, Wright himself states: "'Having left America and having been living for some time in France, I have become concerned about the historical roots and the emotional problems of western whites which make them aggressive toward colored peoples.... I was looking for explanations of the psychological reactions of whites.... In this novel, I have attempted to deal with what I consider as the most important problem white people have to face: their moral dilemma'" (167). Later, in an interview with Georges Charbonnier, Wright delves into the depth of the problem: "I picked a white American businessman to attempt a demonstration about a universal problem...the problem of freedom" (236). Given the overview of the limited body of critical works on the novel, we need to remember Wright's intention in writing it. Wright chooses to write a novel with no explicit 'interracial conflicts,' to demonstrate white people's moral dilemma that causes them to be aggressive to black people. However unpronounced the issue of race may be, an African American novelist's dealing with white people's problem of freedom is a strategy that enables him to make an effective political statement on the positionality of whiteness as an ideology in America that inevitably raises the issue of freedom for black people.

The issue of freedom gains significance in the novel, when Fowler is forced to retire for the simple reason that he "didn't know what to do with himself" (31). The Company made him feel protected but now he feels "trapped in freedom" (33). He starts using his freedom to cover up his indirect responsibility for Tony's death by projecting 
that guilt into Mabel to make her feel responsible for her son's death. He feels his relationship with Mabel should be based on his power to restrict her freedom: "he'd be the boss; he'd dominate her completely..." (134). His plan to marry her to guarantee her silence is rationalized by the act of redeeming her soul. This act of redemption placed him "in the role of a missionary" (134), for "[s] he was begging for guidance" (137). He feels ready to "civilize" Mabel-a positioning that reinforces his superiority. His contempt for her increases, when he thinks about how infamous she is: "...her shameless life had killed her child! And she was too dumb, too sunk in sin to be aware of it" (155). He feels satisfied with "the advantage that his money and social status gave him over her" (123). He transfers his view of the Other as object from a white woman to his colored maid Minnie: "Erskine didn't believe that servants were quite human, but he felt that having them around brought one some standing; one could always depend upon them for simple, human reactions" (140). So Minnie is "socially absent" in his eyes; she is there as a signifier of his social position, reminding one of the slave-master relationship of the antebellum South. As a sexist and classist, he seems quite at ease, when he believes himself completely in power, in feeling the advantage of freedom at his disposal. His mental act of criminalization of Mabel and dehumanization of Minnie introduces the emotional roots of associating white masculinity with power-the mental construct at the basis of racist ideology. Later on in the novel, he feels proud of himself for smashing the doll's head with a brick to take revenge on his mother. He carries the same pride with his murdering of Mabel. He looks at the dead body "with a kind of sullen, stolid pride at the nude, bloody body stretched on the table" (217). His obsession with morality made him a murderer, a scene that can almost be associated with an act of lynching. His sense of freedom is based on his murdering the Other-the object has to be destroyed to make it safe for the Subject.

It is true that the novel challenges our expectations as readers in failing to find what we look for in Wright's canon, namely a black character's confrontation with racism. However, Wright immediately takes a racial stance, when he constitutes a vantage point in enabling us to view the "infamous" behavior of a respectable white male citizen like Fowler, who imagines he is acting unobserved. Fowler embodies the social prerogatives of whiteness, which he loses as he breaks with the conformity that preserves the white race. "The white race," in Noel Ignatiev's and John Garvey's own words, "consists of those who partake of the privileges of the white skin in this society" (Race Traitor 9). Hence, Savage Holiday deals with racism in its sub- 
tleties of dislocating us in relationship to the absence of blackness, rather than to its presence, forcing us to re-enter the omnipresence of the pervasive "cultural whiteness" (Nielsen 15). The deliberate exclusion of the race issue serves as a political act of indicting the master narrative of white American racism, which leaves the "Negro" out of its boundaries of daily existence, because the concepts of cultural whiteness and humanity are generated as interchangeable terms. Given the social geography of race defined as purely white, "the construction of Americanness" (Morrison, Playing 47) is built upon a definition of whiteness that demands the eradication of blackness (not withstanding the other hyphenated social constructions of race and ethnicity). In Savage Holiday Wright works on, to use Gayatri Spivak's words, a shifting of the center "in terms of its own marginality" (40) in order to show what happens when the white American man's social location is threatened by the same social constructs which legitimize black people's oppression. As Toni Morrison contends: "The act of enforcing racelessness in literary discourse is itself a racial act" (Morrison, Playing 46). In this context, the novel demands to be seen in a new light, for it does talk about the white man's construct of whiteness in a country built on white supremacist ideology. Ruth Frankenberg suggests: "Whiteness...has a set of linked dimensions. First, whiteness is a location of structural advantage, of race privilege. Second, it is a 'standpoint,' a place from which white people look at ourselves, at others, and at society" (1). Noel Ignatiev asserts that "The white race consists of those who enjoy the privileges of the white skin's freedom from unreasonable search and seizure, the inside track for jobs and careers" ("To Advance the Class Struggle" 1). Put in this manner, whiteness signifies that which is above and beyond mere skin color. In this respect, the white protagonist Erskine Fowler's mental state of mind seems to signify all the elements of racialized thinking that have long forced African Americans into social invisibility.

In the course of the novel, Fowler takes on many roles whose historical connotations have affected the black situation in America: businessman, missionary, and patriarch. He has worked as a business man-a symbol of the American success myth that imbues him with the security of the American Dream with which he "had locked himself up in a prison-cage of toil" (33). His public image as "a good man, honest, kind, clean, straight - the kind of man who loved children" (34) seems to validate the imperial dynamics of whiteness, which is reinforced in his attitude to women. He feels his bedroom "had never been dishonored by the presence of a stray woman of pleasure" (34). His attitude to women as prostitutes lies at the root of 
hegemonic discourse based on the ideology of difference. In his relationship with Mabel Blake based on a "positional superiority" (Said 7), he takes on the role of a missionary who has to "save" Mabel's soul (a cover-up for his guilt concerning Tony's death), while imposing a degrading image on her-a prostitute. In other words, he is operating within the colonialist discourse whose "overt aim is to 'civilize' the savage..." (JanMohamed 81). Since nakedness is associated with savagery (an uncivilized act), he has the Puritan disgust with his own body: "His hairy body, as he glanced down at it, seemed huge and repulsive, like that of a giant; but, when he looked off, his body felt puny, shriveled like that of a dwarf" (45). Hence he feels a brute-a feeling he quickly abandons in his act of "civilizing" Mabel, who is "a morally depraved woman" (91). He wants to trap Mabel by the ideology of difference that women are sensual and therefore they need to be manipulated by the patriarchal power to be moral, as he treats her as an available social handle to serve his rule in controlling her sexuality. If he can "own" and "control" Mabel's sexuality, he can manage to control her voice. Mabel-a "fallen woman"-serves as the foil of his crime, and he feels satisfied with his "positional superiority." It brings to mind what Sander L. Gilman maintains: "The "white man's burden' thus becomes his sexuality and its control, and it is this which is transferred into the need to control the sexuality of the Other, the Other as sexualized female" (256). Likewise, Fowler develops his relationship with Mabel, shaped in terms of the link between whiteness and domination. If whiteness explicitly signifies wealth and comfort in the novel, then it implicitly signifies a system that perpetuates injustice, because its basic assumption lies on the mythology of oppositionality and hence whiteness becomes, in Teresa de Lauretis's words, a "hostile threatening force" (qtd. in Butler-Evans 3).

After he is forced into early retirement, Fowler loses all the social labels producing the solid sense of whiteness-that is, wealth, privilege, comfort and social acceptance. He is no longer positioned within the "white-skin privilege politics" (Race Traitor 1), as Ignatiev and Garvey would suggest, which produced him as the white middle class man who likes where he stands. Fowler is driven outside the system of white supremacy in being forced into the position of the Other-social invisibility-that subverts the success myth. The scene in which he is locked out of his apartment naked becomes a metaphor for his "homeless" self: Once he is stripped naked of all the social markers, or all the privileges of the white skin in America, he feels homeless. He is insecure about being seen naked, signifying an uncivilized attitude, because he is restless when looked at from a different social location, one of which he is not the center. He, who has 
always indicted his mother's sexuality and has mixed feelings about Mabel's body-"despite his hate, his senses drank in the sensual appeal of her buxom grief-wracked body" (155)-does hate his own naked body, for it distorts the comforting equivalence between whiteness and civilization. Fowler is in fact imprisoned by the stone walls of the master narrative of "white supremacist capitalist patriarchal culture" (hooks, Killing 16).

The childhood scene where he draws the broken doll is repeated over and over again in his mind as he plays with the colored pencils at the beginning and at the end of the novel. This narrative frame displays Fowler's mind as a mental slum which is constricted by the narratives of women's sensuality and beauty which he has to "crush" in order to hold on to his self-definition as a man whose "cultural whiteness" signifies "virtue, purity, and wisdom" (Gaskill 46). His subconscious act as a child for revenge on his mother for leaving him out of her immediate concerns, turns into a conscious act of stereotyping all women as naturally sensual and promiscuous in need of obliteration. His rationalization of forcing Mabel into marriage in his so-called missionary stance shows an indisputable potential oppressor in him-a man without civilization who utilizes his freedom to oppress the Other. This act of utilization indicates something very important in Fowler's character: unable to use his personal freedom in a healthy way, he turns to acting on "sovereignal freedom." As the sociologist Orlando Patterson claims: "Sovereignal freedom.... is simply the power to act as one pleases, regardless of the wishes of others, as distinct from personal freedom, which is the capacity to do as one pleases, insofar as one can" (3-4). For Fowler, stereotyping is not reserved only for women, but for servants including his colored maid Minnie. The servant as object is the signifier of his social status, whereas Mabel, whom he describes as a "cheap, cold monster!" and a "bitch!" (152) is not human enough to bring him any standing. His essentialist reasoning and territoriality show a man who "is sealed in his whiteness" (Fanon 9).

The "Americans' fear of being outcast, of failing, of powerlessness... and their dread of failure" (Morrison, Playing 37) seems to describe Fowler's position whose social exclusion starting with his early retirement from his work, and therefore from the security his public self offers does also mean that he is denied the opportunity to stay white. In a culture where "To be white is...to be culturally inclined toward the making of proper moral and economic choices" (Nielsen 14), Fowler has to appropriate the pattern of oppression by "colonizing" Mabel in speaking for her or talking out at her; by oppressing her in defining her as a "bad mother" and "prostitute"; and 
by exploiting her in trying to force her into a marriage based on false love. In either of these three stages of the pattern of oppression, he commodifies Mabel, who becomes the product of his mind as subhuman. He gets entangled by his own mental constructs in his failure to see the real Mabel as the poor war-widow who is fighting for her life. In reinforcing the stereotypical image of Mabel as savage-an incomplete being in need of Fowler's help to be civilized, to become complete, Fowler re-positions himself as superior to Mabel. He defines Mabel as "a cold monster" (194), "inhuman...brutal" (200) and later as "dirty little whore" (202). Wright earlier indicated that "the white missionary...can never understand that which he calls our 'savage' behavior is the consequence of his zeal to 'save'" (White Man 11). What Fowler fails to realize is that his supremacist stance condones the dehumanization of the Other. Mabel represents another doll to be destroyed, for she has to be sacrificed "to make the world safe for the 'white man's' conception of existence" (White Man 42). Deprived of a viable set of values to survive in the face of social imperatives without which he is unabashedly naked, Fowler embodies "a fantasy of whiteness" (hooks, Killing 36), for which he sacrifices Tony accidentally and Mabel deliberately. He stabs her to death and leaves the corpse on the kitchen table: Fowler's act of murder defines the white male as bestial in dominating and devouring the colonial subject. In many ways, it re-contextualizes bell hooks's statement: "It is by eating the Other (in this case, death) that one asserts power and privilege" (hooks, Black Looks 36). In the scene of murder in the kitchen, Fowler becomes the victim of his rage, whose referentiality is "a sign of powerlessness" (hooks, Killing 12) in Freudian terms. After murdering Mabel he loses his supremacist stance and patriarchal power in the final scene where we see Wright's association of "whiteness with disease" (Gaskill 47). For the first time in his life he has acted out his savage impulses that had long been repressed by the social signifiers of civilization.

One tends to think that if Fowler was not forced into a life of leisure, he would never have a chance to confront the real core of his own self, the very whiteness that revolves around the moral definition and function of freedom. As Alessandro Portelli suggests: "Whiteness...becomes functional to the central symbolism of nakedness, because it stands for a weaker...definition of selfhood propped up by social conventions and power" (1). Fowler's disease becomes visible at a time when he has absolute power to wrestle with "the problem of freedom." Ironically, he becomes a victim of whiteness, when he is stripped naked of its social markers. What he is trapped by, is not merely the psychological problems due to the Oedipal con- 
flict with his mother, but by the "fear of boundarylessness, of Nature... and [the] fear of the absence of so-called civilization" (Morrison, Playing 37). His nakedness pertaining to the image of the Natural Man terrifies him, for he has never lived without social boundaries and social prescriptions. His career as a successful business man shows how well prescribed his life and mindset have been. The "boundarylessness" means living as a Natural Man for which he has never been prepared. As civilization has to devour wilderness and savagery to make itself appear through the absence of its binary opposition, he cannot lead a life of human freedom without inventing an Other to devour. The fear of taking responsibility for a life of freedom represents Fowler's inability to deal with a life beyond boundaries and categorial thinking.

Tony's act of naming makes the invisible Indians visible in order to kill them in a game, is a telling scene which associates killing and playing as a part of cultural conditioning, revolving around the ideology of difference. Wright's novel makes the issue of race quite visible in the implications and connotations of whiteness where the Self (Fowler) cannot live without "eating" the Other (Mabel), for making the signs of difference visible is America's national narrative. The "moral dilemma" Wright wants the white people to face is bound with the larger issues in a world that refuses to kill the "savagery"the mere invention of whiteness. Wright's exclusion of black characters and interracial conflicts from the novel is enough of a political statement on the white supremacist American society. The title of the novel plays an important part in this political statement, for after reading the novel we know that it is not the holiday that is savage (an adjective defining a noun in terms of grammar) but it is Fowler's attitude growing out of the dynamics of social grammar that redefines holiday-freedom utilized savagely. This brings to mind Wright's statement in an earlier speech: "In fact, Asian-African definitions of the word 'savage' shed more light upon the mentality of the Europeans who used it than the objective reality that that word was supposed to describe" (White Man 11). Fowler has to construct "savages" as the Other in order to rationalize his bestial rule over and destruction of them to re-position himself as a civilized man, a true member of the white American Christian civilization. Yet the false values upon which the privilege of the white race rests is revealed in the scene of Fowler's confession to the police. The moment of retirement made him an inevitable "Other," and now he has become nothing but the object he himself invented: From now on, he will be no more than a record in the police files-a case study for experts. The commodification of Fowler's act of "power" then reveals ironically his power- 
lessness in the society. But unlike the black protagonist Bigger Thomas in Native Son, Fowler's whiteness provides him with a domain of freedom where, to use Toni Morrison's comment on O.J.Simpson, he is not "forced to stand in for the entire race" (Birth of Nationhood xxviii).

On the other hand, as Fowler's case suggests, the patriarchal power is maintained through the invention of "the prescribed sexual scenario of submissive female and dominant male..." (Marshall 17). In destroying the Other, Fowler needs a re-positioning of the self, for he is the inventor left without his invention that obscures his positionality. Ending up as a criminal-a marginal man who is a social failure-he is no longer the custodian of power. He continues to use his freedom to re-position himself in relation to Mabel: From now on he will continue voicing her story for her for the police records, a social outcast voicing absence into presence only from the margins. If the Self can only survive by measuring itself against the Other it constructs, then Fowler has to depend on the memory of the Other, be it his mother or Mabel, that is to say the absence of the Other. Yet repositioning himself in relation to an absence makes him too naked to survive in a domain where social imperatives clothe the individuals. The construct of whiteness reinforces the politics of essentialism, as Fowler fails to define the political parameters of gender and patriarchal authority beyond whiteness as the privileged signifier. His savagery undermines the myth of white man as civilized, in his enslavement by his construct of superiority in an "empty quest for pleasure, property, and power" (West 10).

In many ways, Savage Holiday can be related to Wright's canon, for it presents some of the themes and characters consistent with his earlier work. Although Fowler and Bigger in Native Son can be contrasted with each other, there are certain similarities both characters share in their experiences. Both Bigger and Fowler have been emotionally abused without a solid mother figure to look up to. Much like Bigger, who killed Mary accidentally, Fowler also "kills" Tony accidentally. Similarly Bigger kills Bessie Mears and Fowler kills Mabel Blake for the same purpose-to buy their silence. Fowler can be compared with the persona of Black Boy in the sense that both are in need of a nurturing mother, who would demonstrate maternal love, and yet both suffer from the fact that their drives toward love have been twisted at an early age. Likewise, Mabel's son Tony shares the same traumatic experience as the persona of Black Boy of having a mother who fails to fulfill the emotional needs he has. The novel can also be located within the similar contexts of "The Man Who Lived Underground" and Rite of Passage. In both of these works, the protagonists' 
location shifts in the face of a shocking event that brings about a crisis of identity. Fred Daniels in "The Man Who Lived Underground" descends into the underground when the police officers force him to confess to a murder he has never committed. His temporary removal from the real world gives him a different vantage point in seeing through the dark side of the so-called respectable people, and enables him to search for his identity, and hence for meaning in his life. Unfortunately this meaning has no importance whatsoever for the police officer who kills him: "'You've got to shoot this kind. They'd wreck things"" (84). However Fred Daniels dies a "happy" man, for he has achieved self-discovery on the margins of a world which denies him the opportunity to be himself. Similarly, in Rite of Passage, 15-year-old Johnny Gibbs's whole world is crushed, when he is told he has been a foster child-"'all his life had been a lie"" (16). He joins the gang as a substitute for a family, for he decides he "had to go on alone to make a life for himself" (116). Re-locating Savage Holiday within the context of Wright's canon, the novel emerges once again as a "raceless" work with a white protagonist that entails us to see through the lack of referentiality to blackness. Unlike Fred Daniels in "The Man Who Lived Underground," Fowler is incapable of seeking his identity outside the very standards of the "white" world which sets him apart from it by forcing him to "retire" to its margins. Unlike black characters such as Fred Daniels, Johnny Gibbs, Bigger, and the persona of Black Boy, who can achieve their identities in their outsider positioning, Fowler's self-discovery is fake as he fails to learn how to function on the margins of whiteness.

The novel has been the preserve of white male power, displaying the ontology of Fowler's world, while whiteness draws us to its binary opposition-blackness-defined through its absence. The selfreferentiality of blackness then invites us to dispute the assumption at the foundation of the Western mind: "To be is to be white" (Johnson 14). The concept of freedom based on false values demands transcending the binary oppositions of civilization and savagery, the Self and the Other in an attempt to redefine whiteness, which is otherwise associated with powerlessness, weakness, and violence as indicative of the will to power. The racelesssness of the novel then serves as Wright's statement on "the moral dilemma" of the white American patriarchal man who fails to deal with "personal freedom" because he defines it solely in terms of "sovereignal freedom," the act of possessing and dominating the Other. As Wright questions the definition of freedom, built on an identification between the acts of civilizing and oppressing, he invites us to avert our attention from the Other in society (African American) to the Self in this novel (white American 
male) in order to transform the mindset behind the white lenses, and to re-assess our vision of the Self when it is relegated to the status of the Other. Wright defines the Self in confinement, restricted by the rigid social morality imposed on the self. The sociocultural constituents of morality seem to smother the self in pessimistic overtones of guilt and fear of self-confrontation. In fear of the public gaze, that rigid Puritan as he is, Fowler resists the kind of spectacle he would represent to the people, if they saw the "naked" aspects of his own self-the uncivilized man. The idea of not living up to the mores of a "civilized" people, Fowler despises his body, the embodiment of sin, a mentality that can be associated with the representation of the black body as a signifier of sin in its historicity. Wright gets us to see beyond the "white lenses" of Fowler in depicting his fear of the public gaze- the very gaze through which he has always viewed the world. His insecurity emerges from stepping outside of the tenets of civilization and hence from inhabiting a location that would shift into the realm of savagery in the public mind, that is from the Self to the Other. His relocation demands a shift in our positionality as readers: if Fowler has become the Other, where do we stand? If this is the case, then we are bound up with making a moral choice of rebuilding our domain of freedom in an attempt to disrupt the relationship between whiteness and domination in a world which needs to learn new ways to transgress boundaries.

\section{Works Cited}

Barthes, Raymond. "Interview." Conversations with Richard Wright. Ed. Keneth Kinnamon and Michel Fabre. Jackson: U of Mississippi P, 1993. 166-68.

Butler-Evans, Elliott. "Beyond Essentialism: Rethinking Afro-American Cultural

Theory." Online. 6 June 1997. Available: http:/ / epic.cse.ucsc.edu/Classes/cmp186/Projects/CultCtr/pubs/Inscriptio.

Charbonnier, Georges. "A Negro Novel About White People." Kinnamon and Fabre, 235-38.

Fabre, Michel. The Unfinished Quest of Richard Wright. Trans. Isabel Barzun. Urbana: U of Illinois P, 1993.

Fanon, Frantz. Black Skin, White Masks. New York: Grove, 1967.

Frankenberg, Ruth. White Women, Race Matters: The Social Construction of Whiteness.

New York: Routledge, 1993.

Gaskill, Gayle. "The Effect of Black / White Imagery in Richard Wright's Black Boy." Negro American Literature Forum 7 (1973): 46-48.

Gates, Henry Louis, Jr. Ed. "Race," Writing, and Difference." Chicago: U of Chicago P, 1986.

Gilman, Sander L. "Black Bodies, White Bodies: Toward an Iconography of Female Sexuality in Late Nineteenth-Century Art, Medicine, and Literature." Gates 223-61.

Gounard, J.F., and Beverley Roberts Gounard. "Richard Wright's Savage Holiday: 
Use or Abuse of Psychoanalysis?" CLA Journal 22 (1979): 344-49.

Hakutani, Yoshinobu. "Introduction." Critical Essays on Richard Wright. Ed. Y. Hakutani. Boston: G. K. Hall, 1982. 1-35.

hooks, bell. Black Looks: Race and Representation. Boston: South End P, 1992.

. Killing Rage: Ending Racism. New York: Henry Holt, 1995.

Ignatiev, Noel. "To Advance the Class Struggle, Abolish the White Race." Online. 6 June 1997. Available:http:/ / emma.unm.edu/Inr/Inrnov94/ racetrat.html.

Ignatiev, Noel, and John Garvey, eds. Race Traitor. New York: Routledge, 1996.

JanMohamed, Abdul R. “The Economy of Manichean Allegory: The Function of Racial Difference in Colonialist Literature." In Gates, 78-106.

Johnson, Charles. Being and Race: Black Writing Since 1970. Bloomington: Indiana UP, 1988.

Marshall, Annecka. "From Sexual Denigration to Self-Respect: Resisting Images of Black Female Sexuality." Reconstructing Womanhood, Reconstructing Feminism: Writings on Black Women. Ed. Delia Jarrett-Macauley. London: Routledge, 1996. 5-35.

Morrison, Toni. "Introduction." Birth of a Nation'hood: Gaze, Script, and Spectacle in the O.J.Simpson Case. Ed. Toni Morrison and Claudia Brodsky Lacour. New York: Pantheon, 1997. vii-xxviii.

. Playing in the Dark: Whiteness and the Literary Imagination. London: Picador, 1993.

Nielsen, Aldon L. Writing Between the Lines: Race and Intertextuality. Athens: U of Georgia P, 1994.

Patterson, Orlando. Freedom in the Making of Western Culture. Vol. 1. London: Basic, 1991. 2 vols.

Portelli, Alessandro. "Savage Holiday: Nakedness, Whiteness: Defining the Social Self." Richard Wright Newsletter 4 (1996): 1-2.

Reilly, John M. "Richard Wright's Curious Thriller, Savage Holiday." CLA Journal 21 (1977): 218-23.

Said, Edward W. Orientalism. 1979. New York: Vintage, 1994.

Spivak, Gayatri C. "Strategy, Identity, Writing." The Post-Colonial Critic: Interviews,

Strategies, Dialogues. Ed. Sarah Harasym. New York: Routledge, 1990. 35-49.

Vassilowitch, John, Jr. "Erskine Fowler': A Key Freudian Pun in Savage Holiday." English Language Notes 18 (1981): 206-08.

West, Cornel. Race Matters. New York: Vintage, 1994.

Wright, Richard. "The Man Who Lived Underground." Eight Men. 1961. New York: Harper, 1996. 19-84. Rite of Passage. New York: Harper Collins, 1994.

Savage Holiday. 1954. Jackson: UP of Mississippi, 1994.

White Man, Listen!: Lectures in Europe, 1950-1956. 1957. New York: Harper, 1995. 